\title{
PRENATAL DIAGNOSIS AND PERINATAL OUTCOME OF 38 CASES WITH CONGENITAL DIAPHRAGMATIC HERNIA: 8-YEAR EXPERIENCE OF A TERTIARY BRAZILIAN CENTER
}

\author{
Rodrigo Ruano, ${ }^{a}$ Victor Bunduki, ${ }^{a}$ Marcos Marques Silva, ${ }^{b}$ Carlos Tadashi \\ Yoshizaki, ${ }^{a}$ Uenis Tanuri, ${ }^{\mathrm{b}}$ João Gilberto Macksoud, ${ }^{\mathrm{b}}$ and Marcelo Zugaib ${ }^{\mathrm{a}}$
}

Ruano R, Bunduki V, Silva MM, Yoshizaki CT, Tanuri U, Macksoud JG, Zugaib M. Prenatal diagnosis and perinatal outcome of 38 cases with congenital diaphragmatic hernia: 8-year experience of a tertiary Brazilian center. Clinics. 2006;61(3):197-202.

PURPOSE: To evaluate the perinatal results for neonates with congenital diaphragmatic hernia diagnosed prenatally. METHOD: We reviewed data from 38 cases of congenital diaphragmatic hernia diagnosed prenatally from January 1995 to December 2003 in the Fetal Medicine Unit of the Department of Obstetrics and Gynecology, São Paulo University Medical School. The main data analyzed were gestational age at diagnosis, fetal karyotyping, side of diaphragmatic defect, presence of associated structural malformations, hepatic herniation, and severe mediastinal shift. Perinatal outcomes were obtained by reviewing hospital documents or by directly calling the patients' immediate relatives.

RESULTS: Mean gestational age at diagnosis was 29 weeks (range, 16-37 weeks).Thirty (79\%) cases had a left diaphragmatic defect and $8(21 \%)$ had a right lesion. Associated structural malformations were observed in 21 (55\%) cases, in which 12 fetuses had a normal karyotype and 9 had chromosomal abnormalities. Isolated congenital diaphragmatic hernia was confirmed in 17 $(45 \%)$ cases. The overall perinatal mortality rate was $92 \%$. Rates of fetal deaths, early neonatal deaths, late neonatal deaths, and survival were $42 \%, 50 \%, 0 \%$, and $8 \%$, respectively, in cases with associated structural malformations but normal karyotyping; $56 \%, 44 \%, 0 \%$, and $0 \%$ for cases with chromosomal abnormalities; and, $0 \%, 76 \%, 12 \%$, and $12 \%$ in cases with isolated congenital diaphragmatic hernia. The neonatal mortality rate was $89 \%$ in cases with isolated congenital diaphragmatic hernia.

CONCLUSION: Perinatal mortality was very high in prenatally diagnosed cases of congenital diaphragmatic hernia. Earlier perinatal deaths are associated with the presence of other structural defects or chromosomal abnormalities. In cases of isolated congenital diaphragmatic hernia, mortality is related to the presence of herniated liver, right-sided lesion, and major mediastinal shift.

KEYWORDS: Ultrasound. Congenital diaphragmatic hernia. Neonatal mortality. Prenatal diagnosis. Fetal malformation.

\section{INTRODUCTION}

Congenital diaphragmatic hernia $(\mathrm{CDH})$ - consisting of a diaphragmatic defect that starts early in the embryological period, with consequent herniation of the abdominal struc-

\footnotetext{
aDepartment of Obstetrics and Gynecology, Hospital das Clínicas, São Paulo University Medical School.

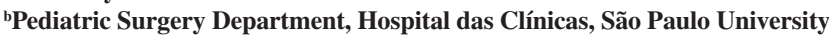
Medical School.

Email: rodrigoruano@hotmail.com

Received for publication on September 26, 2005.

Accepted for publication on February 08, 2006.
}

tures into thoracic cavity - occurs in approximately 1 of 2,200 live births. ${ }^{1,2}$ Herniated abdominal structures, such as stomach and liver, shift fetal lungs, and cause pulmonary hypoplasia, which is responsible for the high neonatal mortality rate. ${ }^{3}$ Although the lungs are shifted during fetal life, the placenta maintains respiratory function, allowing correct gas exchange. However, once the umbilical cord is clamped during birth, the hypoplastic lungs cannot perform adequate gas exchange, leading to severe respiratory distress and neonatal death. ${ }^{4}$

Prenatal diagnosis has improved neonatal outcome worldwide through diagnosis of other associated malfor- 
mations, excluding chromosomal abnormalities, and planning delivery inside a specialized tertiary center. ${ }^{5}$ Before the onset of prenatal sonographic diagnosis, the mortality rate was almost $100 \%$, and $\mathrm{CDH}$ was considered a lethal malformation. ${ }^{6}$ Nowadays, the mortality rate has been decreasing among neonates with isolated $\mathrm{CDH}$, varying from $40 \%$ to $75 \%$ in developed countries. ${ }^{1,7}$ Nevertheless, in spite of the great advances in prenatal and postnatal diagnosis and management, the mortality rate in neonates with isolated $\mathrm{CDH}$ is still high. ${ }^{8}$

Recent research has focused on prenatal predictors of neonatal outcome in isolated $\mathrm{CDH}$ cases, such as lung/head ratio $^{9,10}$ and fetal lung volume, ${ }^{11-16}$ to differentiate cases with a worse prognosis, in which fetal therapy or termination of pregnancy may be indicated, from those with better prognosis, requiring only specialized postnatal care. ${ }^{17-19}$

In spite of the worldwide, published experience, there are no data about perinatal results in cases of prenatally diagnosed $\mathrm{CDH}$ in Brazil. Therefore, we reviewed all cases of prenatally diagnosed $\mathrm{CDH}$ in a specialized tertiary center, focusing on the frequency of associated structural malformations, chromosomal abnormalities, and the mortality rate.

\section{PATIENTS AND METHODS}

We reviewed the prenatal database from January 1995 to December 2003 of the Fetal Medicine Unit of the Department of Obstetrics and Gynecology, São Paulo University Medical School, identifying 38 cases of $\mathrm{CDH}$.

Prenatal characteristics were retrospectively analyzed from the ultrasonographic basic database. The main data analyzed were gestational age at diagnosis, presence of associated structural malformations, fetal karyotyping, side of diaphragmatic defect, mediastinal shift, and liver herniation.

Perinatal outcome was reviewed by consulting prenatal, neonatal, and pediatric databases, as well as from telephone contacts with parents. Cases were classified according to perinatal outcome including fetal death, early neonatal death (from birth to 7 days of life), and late neonatal death (after 7 days of life up to 28 days).

\section{RESULTS}

Among the 38 cases of $\mathrm{CDH}, 30$ (79\%) had left $\mathrm{CDH}$, and $8(21 \%)$ had right $\mathrm{CDH}$. Mean gestational age at diagnosis was 29 weeks of gestation (range, 16-37 weeks). Associated structural malformations were observed in 21 cases $(55 \%)$, of which 12 had normal karyotyping (Table 1). Chromosomal abnormality was observed in 9 cases $(24 \%)$, including trisomy $18(n=4)$, trisomy $13(n=3)$, $46 X X / 47 X X X(n=1)$, and 45X $(n=1)$. These two last fetuses had heart malformations in association with congenital diaphragmatic hernia (interventricular defect and aorta coarctation, respectively).

Table 1 - Description of the associated structural malformations with normal karyotype

\begin{tabular}{lll}
\hline CASE & STRUCTURAL MALFORMATION & KARYOTYPING \\
\hline 1 & Onphalocele & $46 \mathrm{XX}$ \\
2 & Renal dysplasia & $46 \mathrm{XX}$ \\
3 & Spina bifida & $46 \mathrm{XY}$ \\
4 & Occipital ecephalocele & $46 \mathrm{XY}$ \\
5 & Heart defect (Fallot) & $46 \mathrm{XY}$ \\
6 & Dandy Walker & $46 \mathrm{XY}$ \\
7 & Type III adenomatoid malformation & $46 \mathrm{XX}$ \\
8 & Dandy Walker and heart defect & $46 \mathrm{XY}$ \\
9 & Occipital encephalocele and heart defect & $46 \mathrm{XY}$ \\
10 & Hydrocephaly and renal agenesy & $46 \mathrm{XX}$ \\
11 & Spine bifida and left kidney agenesy & $46 \mathrm{XX}$ \\
12 & Renal dysplasia and heart defect & $46 \mathrm{XY}$ \\
\hline
\end{tabular}

The overall mortality was $92 \%$ (35/38). All cases with chromosomal abnormalities died before the 7th day of life (mortality of 100\%). Among the 12 cases with associated structural malformation but normal karyotyping, 11 (92\%) also died before the 7th day of life (including fetal deaths). Among all the cases, only 3 infants with $\mathrm{CDH}$ survived more than 28 days after surgical repair (including 1 neonate with associated omphalocele, but with a normal karyotype) (Table 2).

Isolated $\mathrm{CDH}$ was observed in 17 cases $(45 \%)$. In this group, 15 neonates $(88 \%)$ died. No fetal death was ob-

Table 2 - Perinatal outcome in cases with congenital diaphragmatic hernia according to associated structural and chromosomal abnormalities

\begin{tabular}{|c|c|c|c|c|c|}
\hline & Fetal deathn $(\%)$ & early NNDn (\%) & late NNDn (\%) & Survivaln (\%) & Totaln $(\%)$ \\
\hline Isolated $\mathrm{CDH}$ & $0(0 \%)$ & $13(76.4 \%)$ & $2(11.8 \%)$ & $2(11.8 \%)$ & $17(100 \%)$ \\
\hline $\begin{array}{l}\text { Associated MF with } \\
\text { normal karyotype }\end{array}$ & $5(41.7 \%)$ & $6(50.0 \%)$ & $0(0 \%)$ & $1(8.3 \%)$ & $12(100 \%)$ \\
\hline Chromosomal abnormalities & $5(55.6 \%)$ & $4(44.4 \%)$ & $0(0 \%)$ & $0(0 \%)$ & $9(100 \%)$ \\
\hline
\end{tabular}

CDH: congenital diaphragmatic hernia; MF: structural malformation; early NND: neonatal death before 7 days of life; late NND: neonatal deaths between

7 and 28 days of life; Survival: cases that survived after 28 days of life 
served, 2 neonates (12\%) survived up to the 28 th day of life and 2 neonates (12\%) survived after the 28th day of life (Table 2). Two (12\%) neonates underwent surgical repair after satisfactory ventilatory condition and preoperative stabilization between 10 and 22 days of life. Among the neonates with isolated $\mathrm{CDH}$, the diaphragmatic defect was on the left in $12(71 \%)$ and on the right in $5(29 \%)$. Herniated liver and major mediastinal shift were observed in 7 (41\%) and 13 cases (77\%), respectively. All neonates with a herniated liver or right-sided $\mathrm{CDH}$ died before the 7 th day of life. Among 13 neonates with major mediastinal shift, early death occurred in $10(77 \%)$, while it occurred in 2 of $4(50 \%)$ without this occurrence (Table 3).

Table 3 - Outcome for neonates with isolated $\mathrm{CDH}$, by prenatal ultrasonographic findings

\begin{tabular}{lccc}
\hline & early NND & late NND & survival \\
\hline Side of CDH & 7 & 3 & 2 \\
left CDH & 5 & 0 & 0 \\
rigth CDH & & 0 & 0 \\
$\begin{array}{c}\text { Herniated liver } \\
\text { present }\end{array}$ & 7 & 3 & 2 \\
$\quad$ absent & 5 & 2 & 1 \\
$\begin{array}{l}\text { Major mediastinal shift } \\
\text { present }\end{array}$ & 10 & 1 & 1 \\
absent & 2 & & \\
\hline
\end{tabular}

$\mathrm{CDH}$ : congenital diaphragmatic hernia; early NND: neonatal death before 7 days of life; late NND: neonatal deaths between 7 and 28 days of life; Survival: infants that survived after 28 days of life.

\section{DISCUSSION}

The results demonstrate that other structural abnormalities are frequently associated with $\mathrm{CDH}$ and that perinatal mortality remains very high, even in neonates with isolated $\mathrm{CDH}$. In this series, because termination of pregnancy (TOP) was not performed, it was possible to evaluate the natural history of $\mathrm{CDH}$ in cases with associated structural malformations, chromosomal abnormalities, and even in isolated $\mathrm{CDH}$ cases.

Published reports place the incidence of chromosomal and structural abnormalities in association with $\mathrm{CDH}$ at $35 \%$ to $50 \%$, including trisomies, most commonly trisomy 18. ${ }^{20-22}$ In this study, $55 \%$ of the neonates had associated malformations, and $24 \%$ had chromosomal abnormalities. All neonates with chromosomal abnormalities had other associated structural malformations. Among the neonates with abnormal karyotyping, trisomies 18 and 13 were diagnosed in $4(44 \%)$ and $3(33 \%)$ cases, respectively. Cases with abnormal karyotyping usually have the poorest prognosis, with $100 \%$ perinatal mortality, typically earlier, because fetal death occurred more often $(56 \%)$. In neonates with associated structural malformation but normal karyotype, perinatal mortality was also very high $(92 \%)$. This particular group contributed to the very high perinatal mortality observed in our study, mainly to the earlier deaths, ie, fetal demise (42\%) and early neonatal deaths (58\%). One infant who had an associated omphalocele and normal karyotype survived, probably because of the mild or less severe herniation of abdominal organs into the fetal thorax, leading to milder compression of mediastinal structures and lungs. Both groups are candidates for medical termination of pregnancy (TOP) in countries where this is allowed by the local law.

In cases with isolated $\mathrm{CDH}$, perinatal mortality was higher in our series $(88 \%)$ than reported in the international literature $(50-70 \%){ }^{23,24}$ This could be explained by many factors. First, in our series there was no TOP, while in the international literature, TOP was performed in about $20 \%$ to $30 \%$ of cases. ${ }^{1}$ Second, the main prognostic factor considered was the pulmonary size and/or volume, which is evaluated by the lung-over-head ratio (LOHR) ${ }^{9,10}$ and the observed/expected fetal lung volume ratio (o/e-FLV). ${ }^{12,13,16}$ Cases with LOHR $<1.0$ and o/e-FLV $<0.35$ are associated with poorer outcome (approximately 90\%). In many countries, TOP is performed in cases that have a poorer prognosis, with LOHR $<1.0$, right defect, and liver herniation. In our series, these parameters were not evaluated; therefore, it is not possible to state whether they are similar or comparable populations.

Another possible contributing factor to this difference in perinatal mortality rates is that we included in our study only prenatally diagnosed cases, which are known to have a higher mortality rate than those with only postnatal diagnosis. Skari et $\mathrm{al}^{1}$ observed that neonatal mortality is 2 to 4 times higher in prenatally diagnosed than in postnatally diagnosed series. This possibility is supported when the neonatal mortality of $88 \%$ in our series is considered in the context of the $40 \%$ mortality reported in a previous study published by pediatric surgeons from our hospital; in that study, $\mathrm{CDH}$ was diagnosed postnatally. ${ }^{25}$

Additionally, Harrison et $\mathrm{al}^{17}$ recently demonstrated that adequate and specialized neonatal care can improve neonatal survival to about $70 \%$ in cases with prenatally diagnosed isolated $\mathrm{CDH}$, even in those cases without prenatal treatment. This finding means that each hospital may have different neonatal mortality rates based on the prenatal selection of population, prenatal interventions, degree of specialization of neonatal care group, and type of postnatal treatment. Consequently, meta-analysis and multicenter studies have important inbuilt bias and must be analyzed carefully. Nevertheless, in our series, rightsided lesion as well as major mediastinal shift and herni- 
ated liver were more frequently observed in neonates who died before 7 days of life, and these factors have also been related to a poorer outcome in other studies. ${ }^{1,5,7,16}$

By analyzing the natural history of $\mathrm{CDH}$, the present study is important for demonstrating that each hospital may experience different neonatal mortality rates in isolated $\mathrm{CDH}$. It also motivates us to review our neonatal care and our prenatal evaluation of prognosis as well as to consider fetal interventions in selected cases. By improving the neonatal care and prenatal prediction of perinatal outcome in cases with isolated $\mathrm{CDH}$, minimal fetal invasive surgery could be indicated for those cases with a worse prognosis, based on the fact that we cannot offer TOP to those patients.

\section{RESUMO}

Ruano R, Bunduki V, Silva MM, Yoshizaki CT, Tanuri U, Macksoud JG, Zugaib M. Diagnóstico pré-natal e evolução perinatal de 38 casos de hérnia diafragmática congênita: 8 anos de experiência de um serviço terciário brasileiro. Clinics. 2006;61(3):197-202.

OBJETIVO: Avaliar os resultados neonatais dos casos de hérnia diafragmática congênita com diagnóstico pré-natal. PACIENTES E MÉTODOS: De janeiro de 1995 a dezembro de 2003 foram revisados os dados de 38 fetos com hérnia diafragmática diagnosticada durante o período pré-natal na Unidade de Medicina Fetal do Departamento de Obstetrícia e Ginecologia da Faculdade de Medicina da Universidade de São Paulo. Os dados pré-natais analisados foram: idade gestacional no diagnóstico, cariótipo fetal, lado da lesão, presença de malformação estrutural associada, herniação hepática e desvio garve de mediastino. Os dados perinatais foram avaliados consultando os prontuários médicos ou por contato telefônico.

RESULTADOS: A idade gestacional média no diagnóstico foi de 29 semanas (16-37). Trinta (79\%) casos apresentavam lesão à esquerda e $8(21 \%)$ à direita. Malformações estruturais associadas foram observadas em 21 (55\%) casos, dos quais 12 fetos apresentaram cariótipo normal, enquanto 9 exibiram anomalias cromossômicas. Hérnia diafragmática isolada foi identificada em $17(457 \%)$ casos. A taxa de mortalidade geral foi de $92 \%$. A taxa de óbito fetal, neomorto precoce, neomorto tardio e sobrevivente após 28 
dias de vida foram respectivamente: (i) para o grupo com malformação estrutural associada e cariótipo normal, de $42 \%, 50 \%, 0 \%$ e $8 \%$; (ii) para os casos com cromossomopatia, de $56 \%, 44 \%, 0 \%$ e $0 \%$; (iii) para os casos com lesões isoladas de $0 \%, 76 \%, 12 \%$ e $12 \%$. Na hérnia diafragmática congênita isolada, a mortalidade neonatal foi de $88 \%$.

CONCLUSÃO: Em nosso serviço, a mortalidade perinatal nos casos de hérnia diafragmática diagnosticada durante o pré-natal é muito alta. Óbitos neonatais precoces estão associados com presença de outros defeitos estruturais ou anomalias cromossômicas. Nos casos de HDC isolada, a mortalidade está relacionada à presença de fígado herniado, lado direito da lesão e desvio grave de mediastino.

UNITERMOS: Ultra-sonografia. Hérnia diafragmática congênita. Mortalidade neonatal. Diagnóstico pré-natal. Malformação fetal.

\section{REFERENCES}

1. Skari H, Bjornland K, Haugen G, Egeland T, Emblem R. Congenital diaphragmatic hernia: a meta-analysis of mortality factors. J Pediatr Surg. 2000;35:1187-97

2. Smith NP, Jesudason EC, Losty PD. Congenital diaphragmatic hernia. Paediatr Respir Rev. 2002;3:339-48.

3. Chinoy MR. Pulmonary hypoplasia and congenital diaphragmatic hernia: advances in the pathogenetics and regulation of lung development. J Surg Res. 2002;106:209-23.

4. Bunduki V, Ruano R, Zugaib. Malformações torácicas não-cardíacas. In: Zugaib M. Medicina Fetal. Segunda edição. Editora Atheneu. 1997. p. 227.

5. Harrison MR, Adzick NS, Estes JM, Howell LJ. A prospective study of the outcome for fetuses with diaphragmatic hernia. JAMA. 1994;271:382-4.

6. Jaffray B, MacKinlay GA. Real and apparent mortality from congenital diaphragmatic hernia. Br J Surg. 1996;83:79-82.

7. Dommergues M, Louis-Sylvestre C, Mandelbrot L, Oury JF, Herlicoviez M, Body G, et al. Congenital diaphragmatic hernia: can prenatal ultrasonography predict outcome? Am J Obstet Gynecol. 1996;174:1377-81.
8. Dimitriou G, Greenough A, Davenport M, Nicolaides K. Prediction of outcome by computer-assisted analysis of lung area on the chest radiograph of infants with congenital diaphragmatic hernia. J Pediatr Surg. 2000;35:489-93.

9. Metkus AP, Filly RA, Stringer MD, Harrison MR, Adzick NS. Sonographic predictors of survival in fetal diaphragmatic hernia. J Pediatr Surg. 1996;31(1):148-51; discussion 151-2.

10. Lipshutz GS, Albanese CT, Feldstein VA, Jennings RW, Housley HT, Beech R, et al. Prospective analysis of lung-to-head ratio predicts survival for patients with prenatally diagnosed congenital diaphragmatic hernia. J Pediatr Surg. 1997;32:1634-6.

11. Walsh DS, Hubbard AM, Olutoye OO, Howell LJ, Crombleholme TM, Flake AW, et al. Assessment of fetal lung volumes and liver herniation with magnetic resonance imaging in congenital diaphragmatic hernia. Am J Obstet Gynecol. 2000;183:1067-9.

12. Mahieu-Caputo D, Sonigo P, Dommergues M, Fournet JC, Thalabard JC, Abarca C, et al. Fetal lung volume measurement by magnetic resonance imaging in congenital diaphragmatic hernia.BJOG. 2001;108:863-8

13. Paek BW, Coakley FV, Lu Y, Filly RA, Lopoo JB, Qayyum A, et al Congenital diaphragmatic hernia: prenatal evaluation with MR lung volumetry—preliminary experience. Radiology. 2001;220:63-7. 
14. Ruano R, Benachi A, Martinovic J, Grebille AG, Aubry MC, Dumez Y, et al. Can three-dimensional ultrasound be used for the assessment of the fetal lung volume in cases of congenital diaphragmatic hernia? Fetal Diagn Ther. 2004;19:87-91.

15. Ruano R, Joubin L, Sonigo P, Benachi A, Aubry MC, Thalabard JC, et al. Fetal lung volume estimated by 3-dimensional ultrasonography and magnetic resonance imaging in cases with isolated congenital diaphragmatic hernia. J Ultrasound Med. 2004;23:353-8.

16. Ruano R, Benachi A, Joubin L, Aubry MC, Thalabard JC, Dumez Y, et al. Three-dimensional ultrasonographic assessment of fetal lung volume as prognostic factor in isolated congenital diaphragmatic hernia. BJOG. 2004;11:423-9.

17. Harrison MR, Keller RL, Hawgood SB, Kitterman JA, Sandberg PL, Farmer DL, et al. A randomized trial of fetal endoscopic tracheal occlusion for severe fetal congenital diaphragmatic hernia. N Engl J Med. 2003;349:1916-24.

18. Deprest J, Gratacos E, Nicolaides KH; FETO Task Group. Fetoscopic tracheal occlusion (FETO) for severe congenital diaphragmatic hernia: evolution of a technique and preliminary results. Ultrasound Obstet Gynecol. 2004;24:121-6.

19. Flake AW, Crombleholme TM, Johnson MP, Howell LJ, Adzick NS. Treatment of severe congenital diaphragmatic hernia by fetal tracheal occlusion: clinical experience with fifteen cases. Am J Obstet Gynecol. 2000;183:1059-66.
20. Manni M, Heydanus R, Den Hollander NS, Stewart PA, De Vogelaere C, Wladimiroff JW. Prenatal diagnosis of congenital diaphragmatic hernia: a retrospective analysis of 28 cases. Prenat Diagn. 1994;14:18790 .

21. Thorpe-Beeston JG, Gosden CM, Nicolaides KH. Prenatal diagnosis of congenital diaphragmatic hernia: associated malformations and chromosomal defects. Fetal Ther. 1989;4:21-8.

22. Huddy CL, Boyd PA, Wilkinson AR, Chamberlain P. Congenital diaphragmatic hernia: prenatal diagnosis, outcome and continuing morbidity in survivors. Br J Obstet Gynaecol. 1999;106:1192-6.

23. Flake AW. Fetal surgery for congenital diaphragmatic hernia. Semin Pediatr Surg. 1996;5:266-74

24. Clark RH, Hardin WD Jr, Hirschl RB, Jaksic T, Lally KP, Langham MR $\mathrm{Jr}$, et al. Current surgical management of congenital diaphragmatic hernia: a report from the Congenital Diaphragmatic Hernia Study Group. J Pediatr Surg. 1998;33:1004-9.

25. dos Santos LR, Maksoud-Filho JG, Tannuri U, Andrade WC, Maksoud JG. Fatores prognósticos e sobrevida neonatal na hernia diafragmática congênita. J Pediatr (Rio J). 2003;79:81-6. 